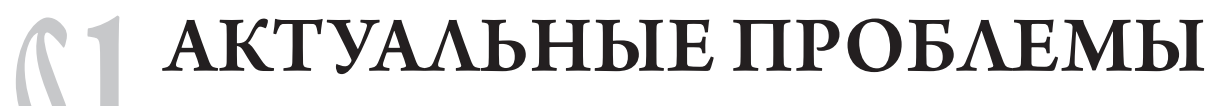 И НАПРАВ АЕНИЯ РАЗВИТИЯ СОВРЕМЕННОЙ КОНФАИКТОАОГИИ
}

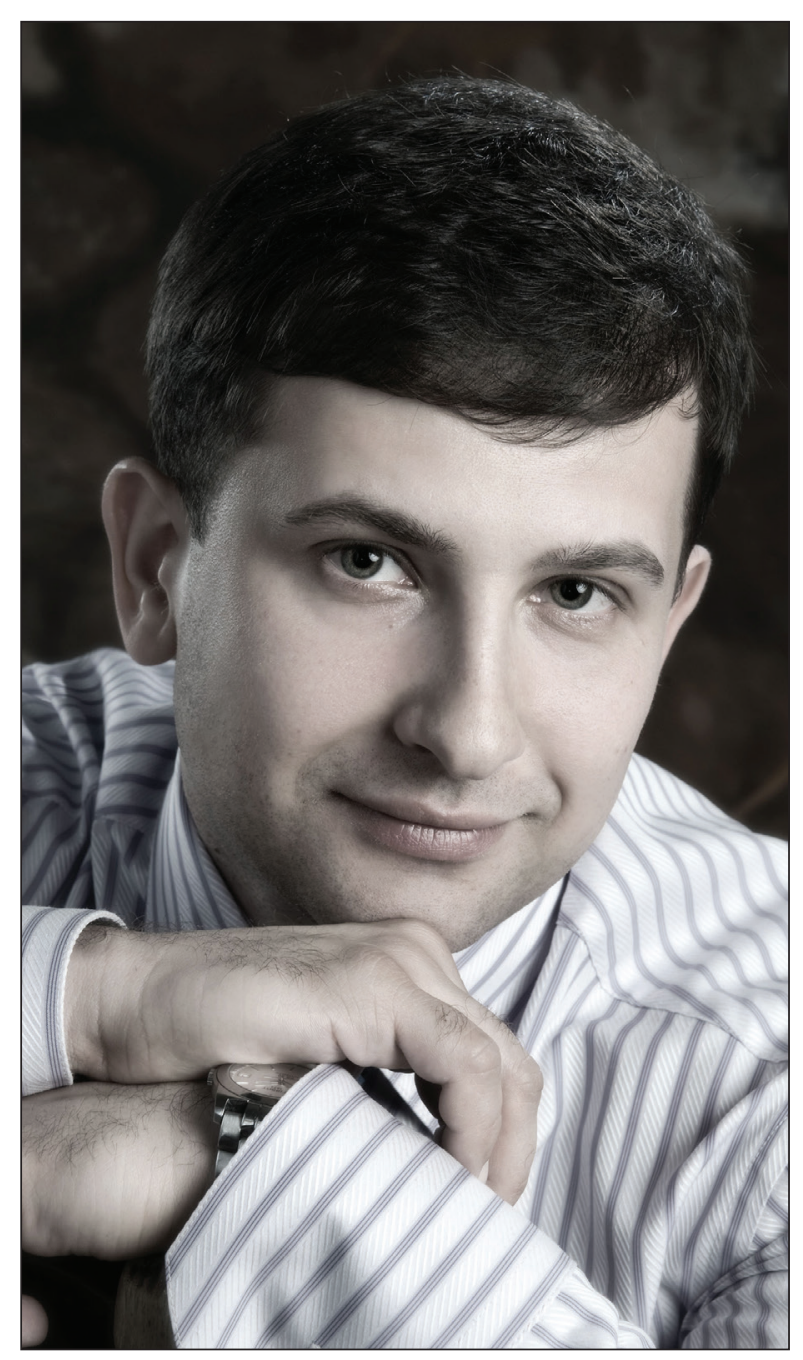

\author{
Манойло А.В. \\ ВСТУПИТЕ АЬНОЕ САОВО \\ ГААВНОГО РЕААКТОРА
}

Ключевые слова: Конфликтология, внешняя политика, Россия, геополитика, конфликты, диплматия, государство, интересы, ценности, безопасность.

\section{АОРОГИЕ ЧИТАТЕАИ!}

Т редлагаемый Вашемувниманию журнам посвящен исследованию прироАы современныхконфмиктов, а также способов, метоАов, инструментов, технологий и процеАур их мирного урегумирования, разрешения.

Тематика исследования конфликтов приобретает в современных условиях необычайную остроту и актуацьность. Современные конфмикты затрагивают практически все сферы общественных отношений: политику, экономику, социацьные отношения, а также отношения межгрупповые, внутригрупповые и межличностные. Природа возникновения и эволюции многих из них чрезвычайно 
сложна, а течение - непредсказуемо. Вместе с тем, важно понимать, что конфмикты в межАУнароАных отношениях явАяются оАной из естественных форм помитического взаимодействия, без которой эволюция мировой политической системы попростуневозможна.

Современные конфкикты не томько позвоцяют выявцять и разрешать противоречия, возникающие в результате развития системы международных отношений, но и вырабатывать новые формы политического поведения в экстремацьных ситуациях, повышающие Устойчивость всей системы межАународных отношений в целом. В мировой помитике межАународные конфмикты становятся очагами помитической модернизации, генераторами изменений и инноваций, меняющих современный мир и наши преАставления о нем. Вместе с тем, наиболее опасные международные конфиикты потрясают сами основы мировой системы, порожАая в ней глобамьные изменения, разцомы и сАвиги, ставшие привычными симптомами кризиса однопомярного мира. На смену инструментам траАиционной Аипломатии в управлении конфмиктами все чаще применяются технологии цветных революций, преследующие цель демонтажа неугодных Западу политических режимов. Все это происходит на фоне нарастающей глобамьной нестабимьности и хаотизации межАународных отношений, погружения мира в «управляемый хаос», в пучину борьбы с сетевыми формами межАународного терроризма и помитического экстремизма, противодействию возрожАению нацизма.

Все это намечает определенный спектр научных проблем и направмений, разработке которых и буаут посвящены рубрики нашего журнаца. При этом мы не будем ограничи- ваться рассмотрением только политических конфмиктов; не меньшее внимание будет уАе$\Lambda$ яться конфмиктам в экономической, правовой, социамьной и межмичностной сферах, конфииктам в экономической конкуренции, связанных с Аеятельностью бизнес-разведок и с противодействием рейдерским захватам и корпоративному шантажу.

Как научный журнам академического профимя, журнац «Конфмиктология» буАет УАемять повышенное внимание фундаментальным исследованиям в сфере урегулирования и разрешения современных конфмиктов, вопросам теории и методологии, концептуа$\Lambda$ изации новых ПоАхоАов, ПроАвижению ценностей российской цивимизации. РеАакция журнала придерживается принципов научной объективности и исторической обусловленности политических процессов, происхоАящих сегодня в мире.

Мы будем рады приветствовать Вас, Аорогой читатець, на страницах нашего журнама и жАем от наших будущих авторов интересных, искрометных и насыщенных острой конмиктологической пробцематикой научных статей. Призываем Вас объеАинить наши уси$\Lambda$ ия на пути к прогрессу и вместе развивать российскую науку!

\section{С уважением,}

Андрей Викторович Манойло

Главный редактор международного научного журнала «Конфликтология», доктор помитических наук, кандидат физико-математическихнаук, профессор МГУимени М. В. Аомоносова, заместитель директора Института стратегчческих исследований и прогнозов PУАH 